\title{
Radiometric Characteristics of the Rio do Peixe Basin- Brazil
}

\author{
Tainá de Melo Ribeiro \\ Scientific Initiation Student, \\ Faculdade Católica Salesiana de \\ Macaé, \\ Macaé, Rio de Janeiro, Brazil \\ tatademelloribeiro@hotmail.com
}

\author{
Maria Julia Siqueira Ferreira dos \\ Santos \\ Scientific Initiation Student, Faculdade \\ Católica Salesiana de Macaé, \\ Rio das Ostras, Rio de Janeiro, \\ Brazil
}

\author{
Brenda Pinto Muniz \\ Scientific Initiation Student, \\ Faculdade Católica \\ Salesiana de Macaé, \\ Macaé, Rio de Janeiro, \\ Brazil
}

\author{
Hans Schmidt Santos \\ Full Professor, \\ Faculdade Católica Salesiana de Macaé, \\ Macaé, Rio de Janeiro, Brazil
}

\author{
Alice Dames Vieira \\ Scientific Initiation Student, \\ Faculdade Católica Salesiana de Macaé, \\ Macaé, Rio de Janeiro, Brazil
}

\begin{abstract}
This paper presents the analysis of radiometric data from an aerial survey carried out in the Rio do Peixe Basin, which is a promising oil-producing region in the state of Paraíba, Brazil. The data collected through gamma spectrometer allowed the preparation of counting maps of Uranium, Potassium and Thorium, allowing to evaluate and compare the radiometric concentrations obtained with the geological and land use maps of the region. The radiometric maps of total and ternary counting illuminated the basin lineaments. The potassium, thorium and ternary maps allow to identify the geological formations of Rio Piranhas, Sousa and Antenor Navarro, contributing to the geological knowledge of the region.
\end{abstract}

\section{Keywords}

Radiation. Gamma Ray. Radiometry. Rio do Peixe Basin.

\section{INTRODUCTION}

Radiometry is dedicated to the study of radioactive energy transfer, based on the measurement and subsequent interpretation of radioactivity from rocks and minerals in the soil and subsoil. This technology using airborne sensors began in 1940 for military purposes in the context of World War II [1]. According to Kearey, Brooks and Hill (2002) [2], among the chemical elements present in minerals and rocks that form the Earth, natural radioactive elements arouse special interest for their economic and strategic value and for their usefulness in methods, through the isotopic ratio between the various radioactive elements, such as uranium, thorium and potassium, and their radioactive series. Therefore, the evaluation of these elements through the radiometric method will be applied to the sedimentary basin of Rio do Peixe, which is an important region with proven petroleum systems. The Rio do Peixe basin is

\begin{abstract}
located on the edge of the state of Paraíba, with a small western portion in Ceará. It belongs to the group called Interior Basins of the Northeast, covering an area of $1,424 \mathrm{~km}^{2}$. The basin is divided into three sub-basins that correspond to "Triunfo" also called "Brejo das Freiras", "Souza" and Pombal" [3].

The basin is one of the main basins of eocretaceous age in the Northeast of Brazil, it contains important paleontological sites. It is located in an attractive set of mesozoic basins of medium dimensions, which present productive areas and with favorable indications of oil and gas [4].

In this work, section 2 presents topics related to the region of study, namely: location, geology and tectonics. Section 3 comments on radioactivity, addressing its concept, elements and the radiometric method. Section 4 discusses the processing and results of the paper, presenting and explaining the potassium, thorium and uranium count maps, total count map and ternary map. Section 5 summarizes the main results obtained and the conclusions of this work.
\end{abstract}

\section{CHARACTERISTICS OF THE AREA 2.1 Location}

The Rio do Peixe Sedimentary Basin is located in the northwest of the Paraíba state (Figure 1). It covers an area of $1,424 \mathrm{~km}^{2}$ with an elliptical shape between the meridians $37^{\circ} 47^{\prime} 00^{\prime \prime}$ and $38^{\circ} 50^{\prime} 00^{\prime \prime}$ west longitude and between the parallels $06^{\circ} 25^{\prime} 00^{\prime \prime}$ and $06^{\circ} 50^{\prime} 00^{\prime \prime}$ south latitude. It is distributed among the municipalities of Pombal, Aparecida, Sousa, São João do Rio do Peixe, Triunfo, Santa Helena, Poço José de Moura, Uiraúna and Umarí [5]. The access can be made by federal highways, BR230 (from Campina Grande), and by BR-405 (from Cajazeiras to Uiraúna), or by Salgueiro-PE or Fortaleza-CE, both using the opposite directions to BR-116, until reaching the FelizardoCajazeiras interchange. 
Radiometric Characteristics of the Rio do Peixe Sedimentary Basin- Brazil

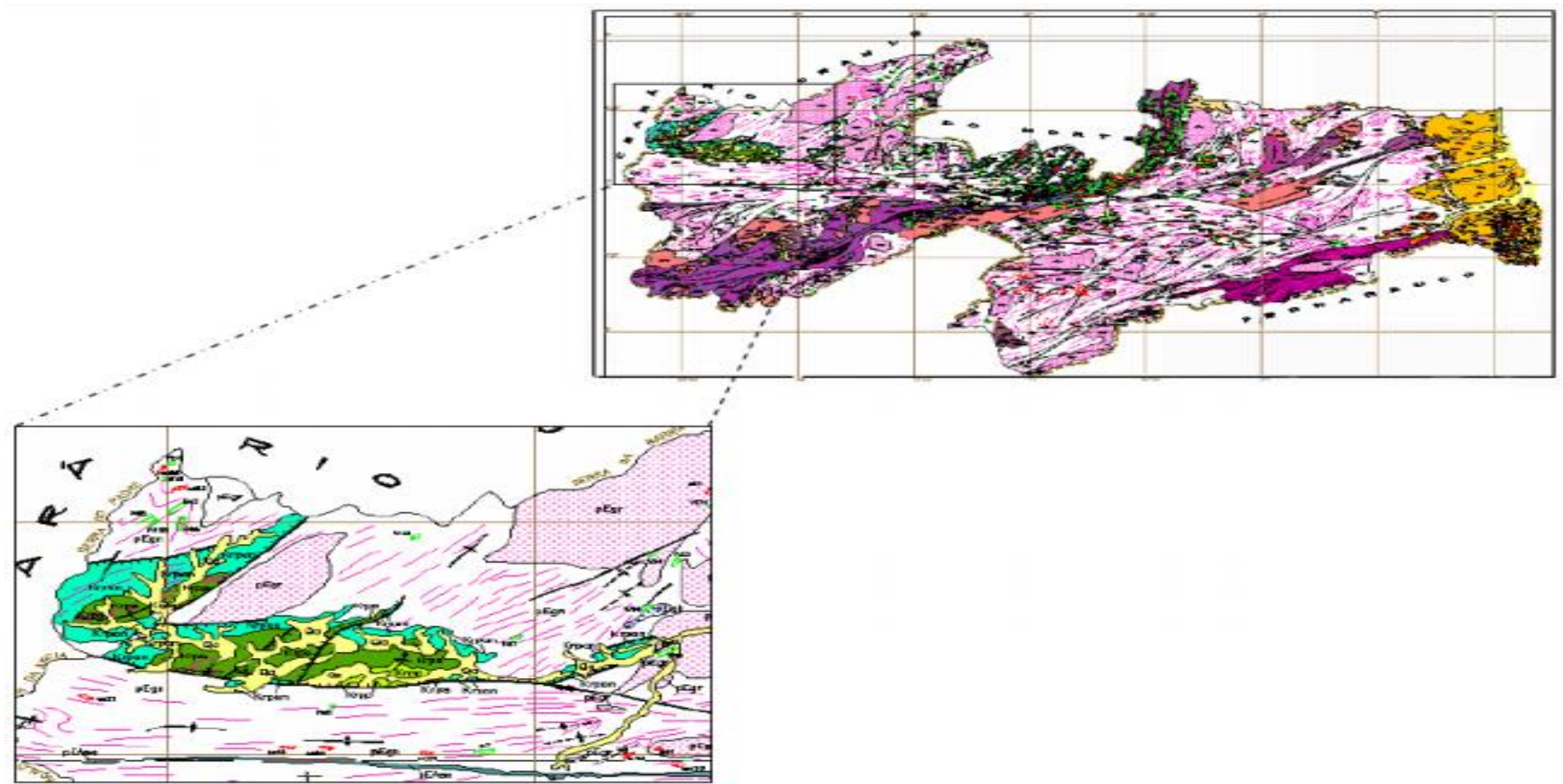

Figure 1: Location of the Rio do Peixe Basin in the Paraíba state [5].

\subsection{Geology}

According to Silva (2009) [3], the basin is divided into three sub-basins that correspond to the Triunfo or Brejo das Freiras, Souza and Pombal (Figure 2).

Lima Filho (1991) [6] characterized lithophagologically the formations of the Rio do Peixe Basin. The Antenor Navarro formation was described as composed by conglomeratic sandstones with thick Arcosian sandstones, associated with medium to fine sandstones. This formation would have been

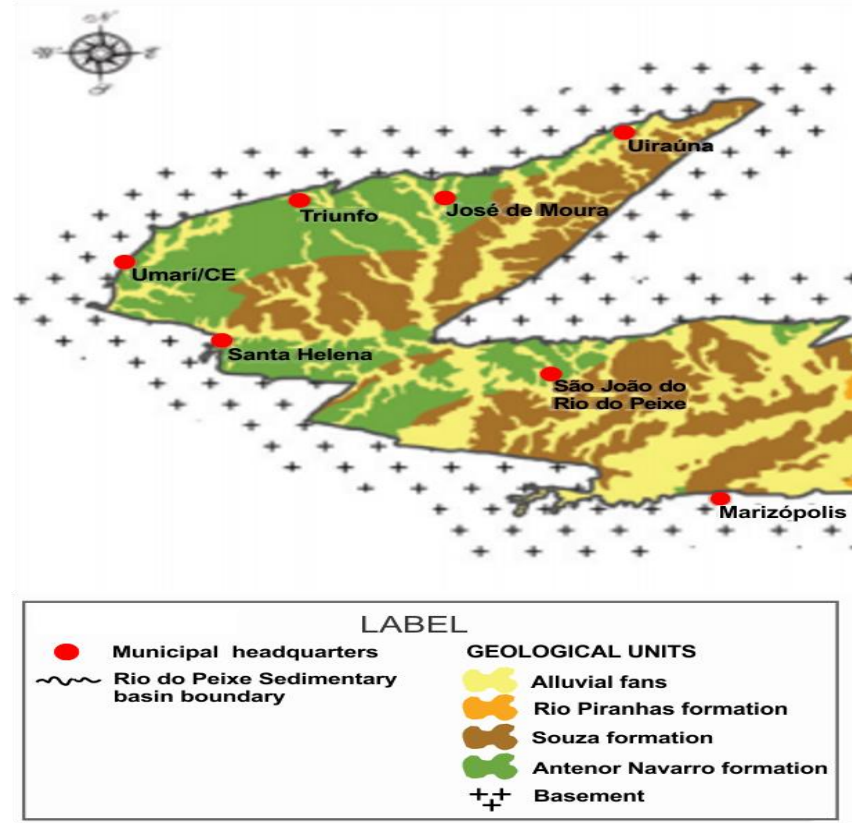

generated by a river system and by alluvial fans. The Sousa formation was characterized by the predominance of brownish red shales and siltstone interspersed with fine to medium sandstones (calcareous), in addition to limestone. In the upper unit there is a sandy sequence with pelites, while in the lower one there is a notable inversion, with dominance of siltstones and shales.

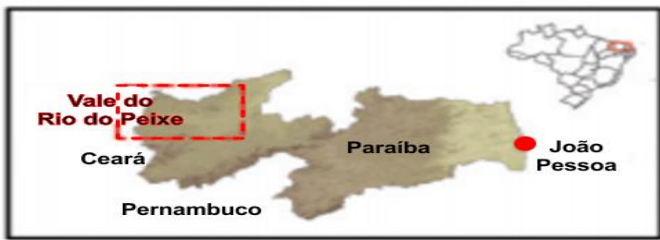

Figure 2: Geological Map of the Rio do Peixe Basin 
The author suggested that sedimentation occurred in calm waters, in a shallow lake or floodplain environment, with river influence. The Rio Piranhas formation is composed predominantly of thick to conglomeratic feldspar, lithic and reddish claystones. The influence of tectonism during sedimentation in the basin is recognized.

\subsection{Topography}

The topographic map of the Rio do Peixe Sedimentary Basin was made using the Topex Topography v 16.1 model with 2D and $3 \mathrm{D}$ views according to Figures 3 and 4 .

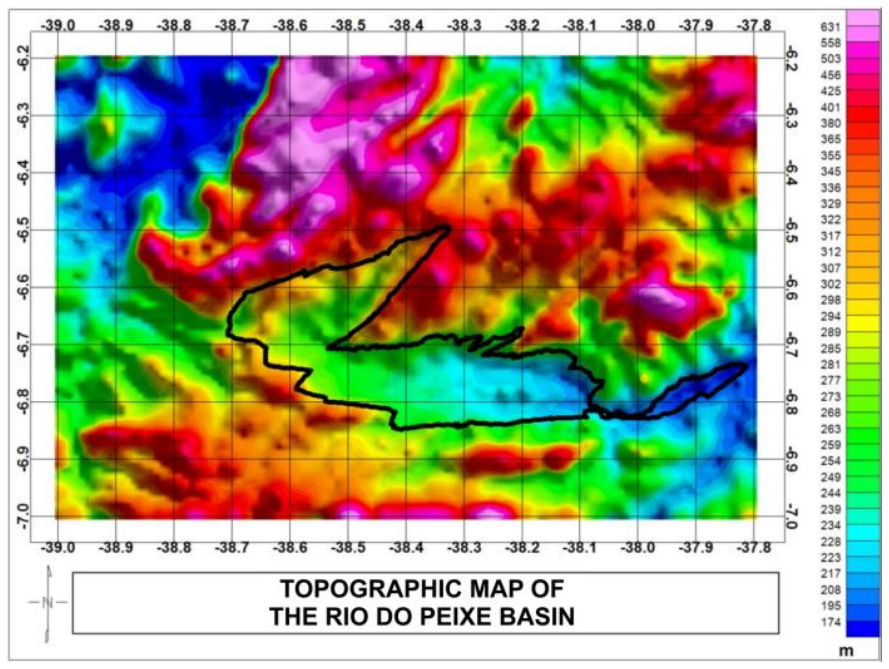

Figure 3: Topographic map of the Rio do Peixe Basin (2D view).

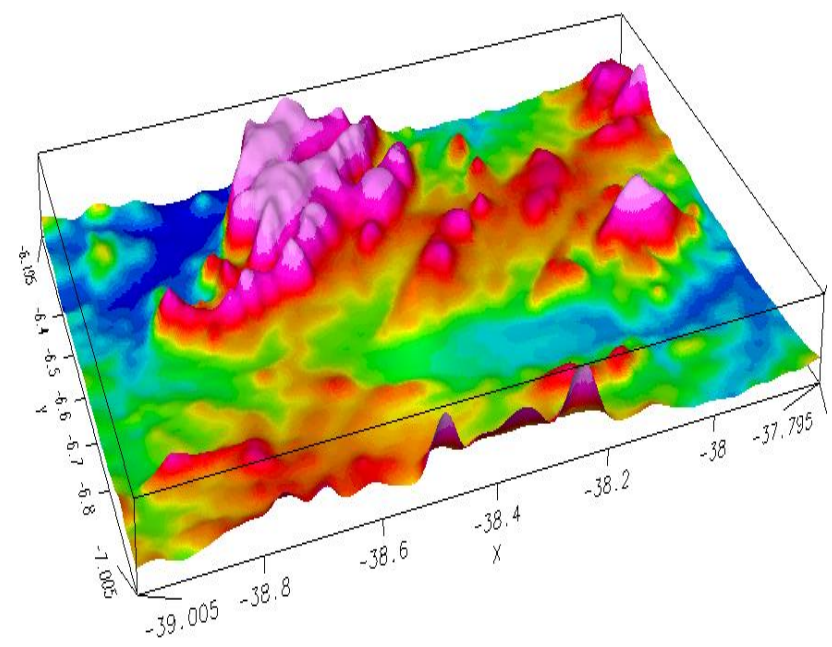

Figure 4: Topographic map of the Rio do Peixe Basin (3D view).
Topographic maps locate the basin in a depression located around 200 meters in altitude limited by plateaus to the north and south that reach just over 600 meters.

\section{RADIOMETRIC METHOD}

Radioactivity is a phenomenon in which an unstable nucleus of a chemical element, usually of high atomic number, spontaneously emits particles and/or electromagnetic radiation to achieve nuclear stability. After this emission, the nucleus changes, which is called transmutation or decay of one chemical element in another. Radioactivity can be classified in two ways: spontaneous, occurring in elements and their isotopes found naturally, and artificial/induced, caused by nuclear transformations, usually in reactors. Most atoms emit only one type of particle, although it is possible to emit more than one type of particle. Artificial transmutation is linked to the bombardment of atoms by means of accelerated particles (alpha, beta, proton, neutron, positron and deuteron particles). Then, there is a transformation of the atom into another element, which are induced in the laboratory [8]. The potassium $(\mathrm{K})$, uranium (U) and thorium (Th) are the major contributors to the radioactivity of rocks, with potassium being the most abundant. The main sources are potassium feldspars, muscovites and biotites. Uranium and thorium can be found in smaller quantities in quartz and feldspars, but in greater quantities in zircon, epidote, monazite and apatite. In igneous rocks, radioactivity can vary widely [11] [12]. The radiometric method (Figure 5) is based on the measurement of gamma ray spectrometry, using detectors. On a large scale, aircraft can acquire the data. After that, they undergo corrections and are then processed to generate images of the surface with concentrations of thorium, uranium and potassium [13].

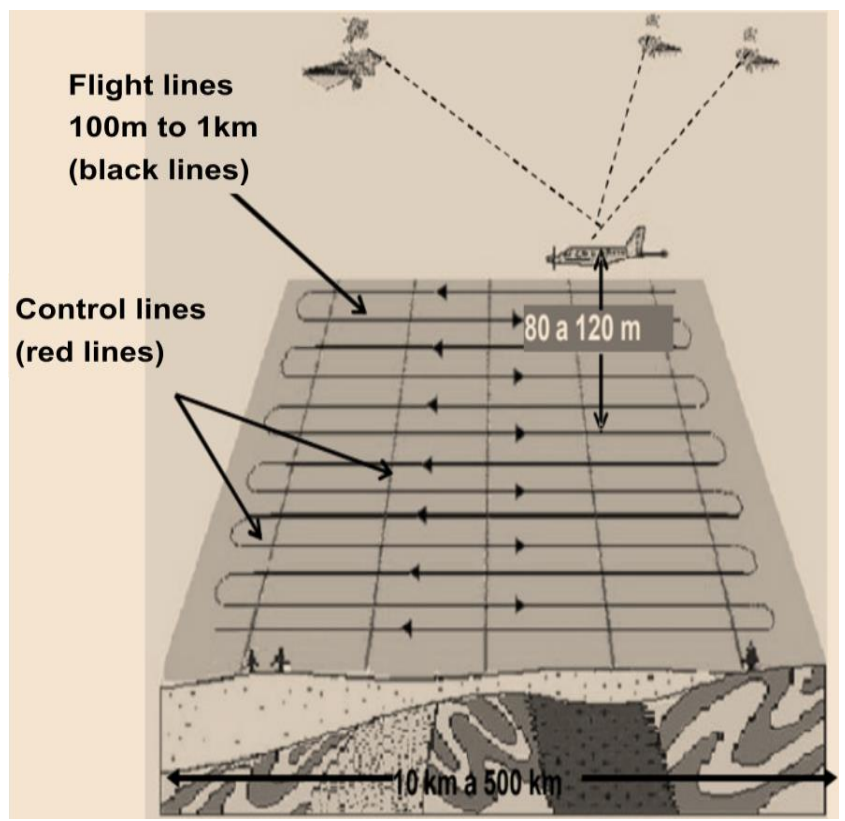

Figure 5: Example of data acquisition by aerial survey. 
According to Sá et al. (2017) [15], the radiometric method can be performed using aircraft, field vehicles, among others. Land and air measurements can cover large areas of the Earth's surface. There are several types of detectors, in which the results are presented as the counting number per second (CPS) and can be converted later to $\%$ or $\mathrm{ppm}$ of uranium, thorium and potassium in the rocks can be converted. According to Brito et al. (2002) [16], the radiometric method is widely used in mineral prospecting, monitoring the natural radiation of the environment and assessing the radioactivity of materials. Aerial radiometry occurs with low-altitude flights, since gamma radiation from radioactive sources decreases greatly with distance due to atmospheric attenuation. Flight lines are often made in parallel and flown perpendicular to the geological direction to define better images. The detectors can reach more than 50 liters of NaI (Tl) crystals, being this volume the controller of the data [17]. According to Kearey, Brooks and Hill (2002) [2], data are collected through the measurement of gamma photons within a specific window of 0.41 to $2.81 \mathrm{MeV}$ (Figure 6). In this interval, each element is associated with a channel of the spectrometer centered on the energies $1.76 \mathrm{MeV}$ (uranium) $2.62 \mathrm{MeV}$ (thorium) and $1.46 \mathrm{MeV}$ (potassium).

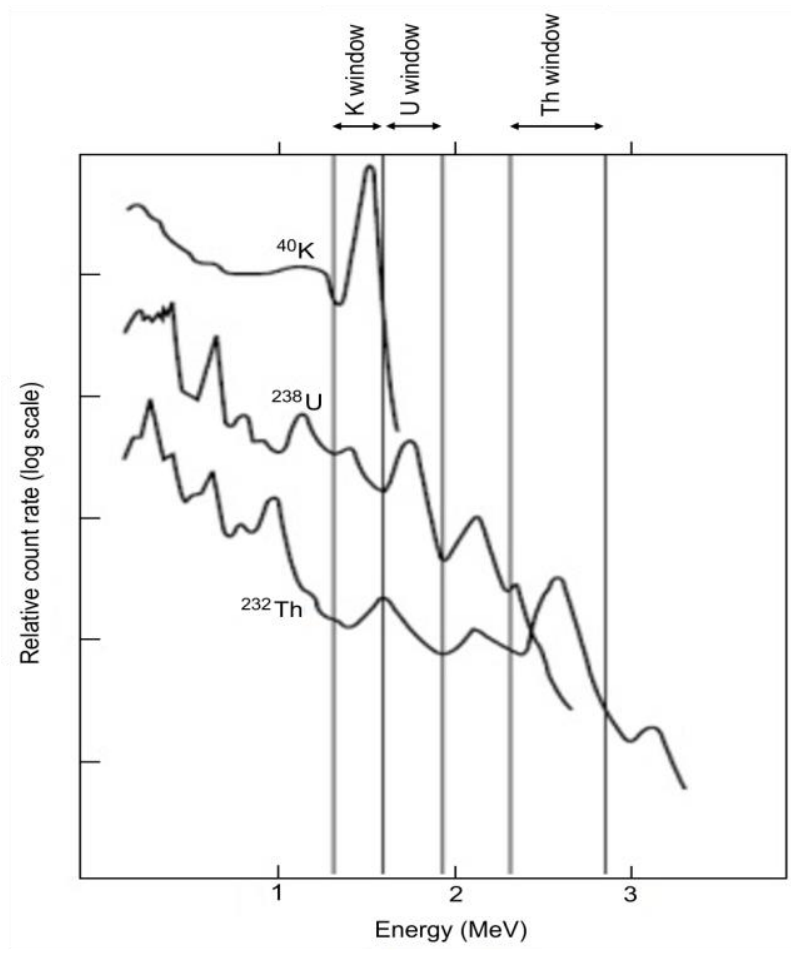

Figure 6: Gamma ray spectrum of $238 \mathrm{U}, 232 \mathrm{Th}, 40 \mathrm{~K}$ and their measurements at 1.76, 2.62 and 1.46 MeV, respectively [2].

\section{PROCESSING AND RESULTS}

Aerial spectrometry data from the Iguatu project were collected using gamma spectrometer DIGRS-3001 from Exploranium and G-800 from Geometrics with thallium-activated sodium iodide detector crystals. The profiles were spaced $1 \mathrm{~km}$ apart and flown 150 meters high by Islander and Bandeirantes aircraft as shown in figure 7.

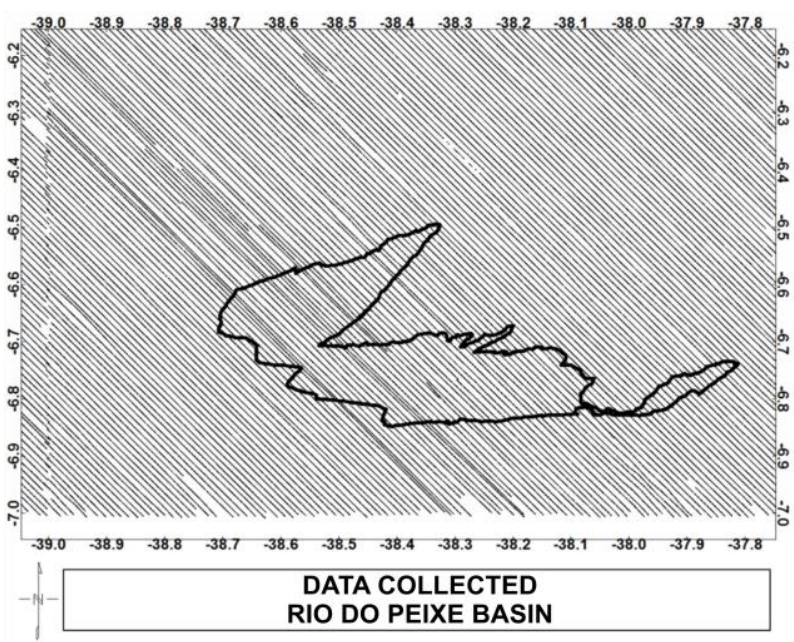

Figure 7: Data collected in the Iguatu project.

The map in figure 8 shows the two-dimensional image of the potassium window.
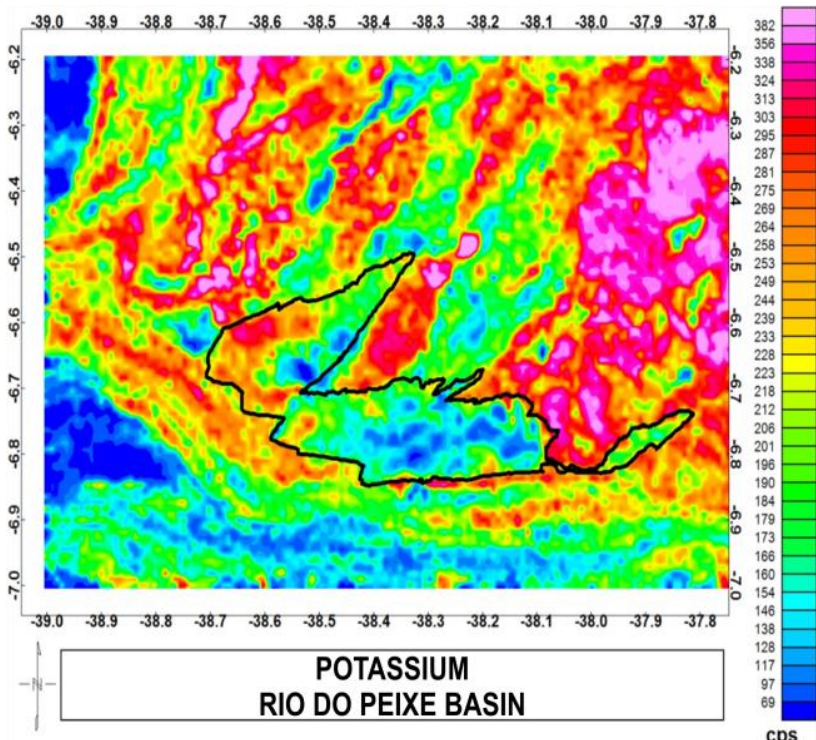

Figure 8: Two-dimensional image of the potassium counting map.

The comparison of the Potassium map with the geological map (Figure 2) shows the low potassium count in the whole Sousa formation with counts between 70 and $170 \mathrm{cps}$ associated with clay, shales and sandstones. A higher potassium count was noticed in the Piranhas river formation with around $280 \mathrm{cps}$ associated with sandstones and in the Antenor Navarro 
formation, reaching more than $300 \mathrm{cps}$ in the Triunfo sub-basin and $220 \mathrm{cps}$ in the Pombal sub-basin.

The map in figure 9 shows the two-dimensional image of the thorium window.

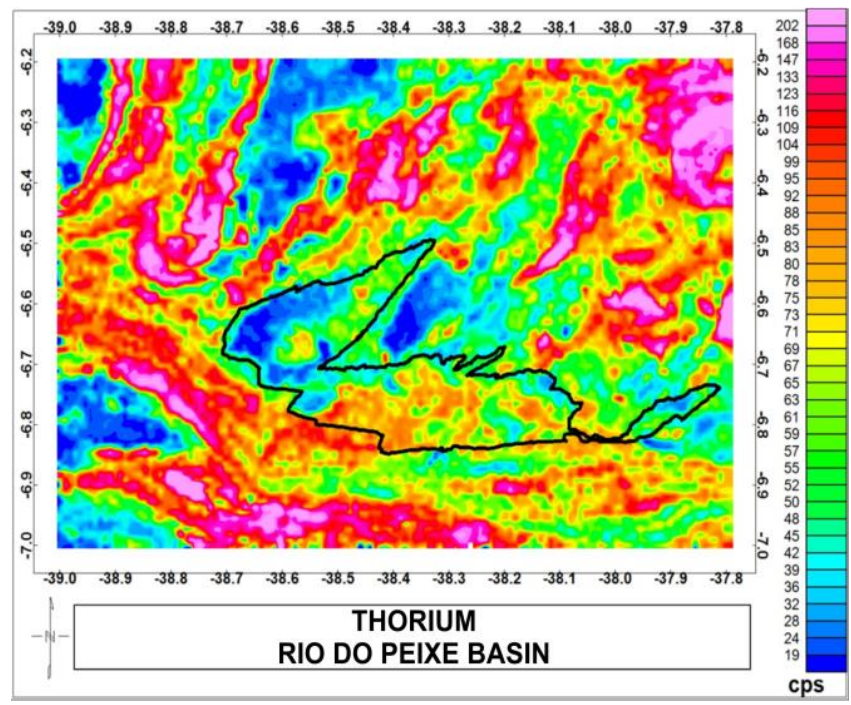

Figure 9: Two-dimensional image of the Thorium count map

The comparison of the Thorium map with the geological map (Figure 2) shows the high Thorium count in the entire Souza formation with counts greater than $100 \mathrm{cps}$ associated with clay, shales and sandstones. A lower thorium count was noticed in the Piranhas river formation with around $50 \mathrm{cps}$ associated with sandstones and in the Antenor Navarro formation reaching counts less than $20 \mathrm{cps}$ both in the Triunfo sub-basin and in the Pombal sub-basin.

The map in figure 10 shows the two-dimensional image of the uranium window.

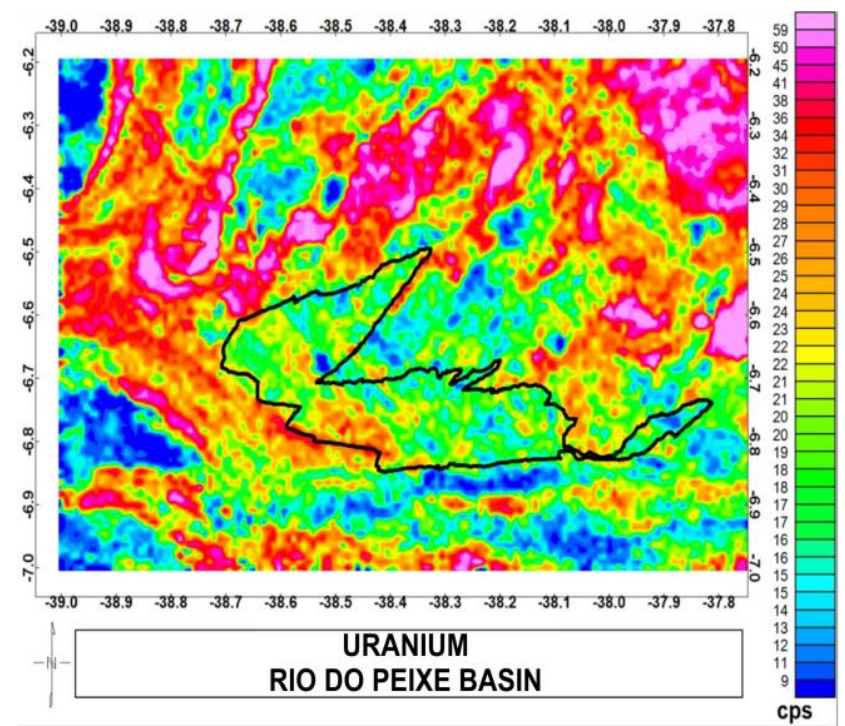

Figure 10: Two-dimensional image of the uranium counting map
The comparison of the map with figures 2 and 3 shows that the Rio do Peixe basin in general presented intermediate counts around $20 \mathrm{cps}$ for the most part. The highest counts occurred in the basement around the basin at higher altitudes.

The map in figure 11 shows the two-dimensional image of the total count window.

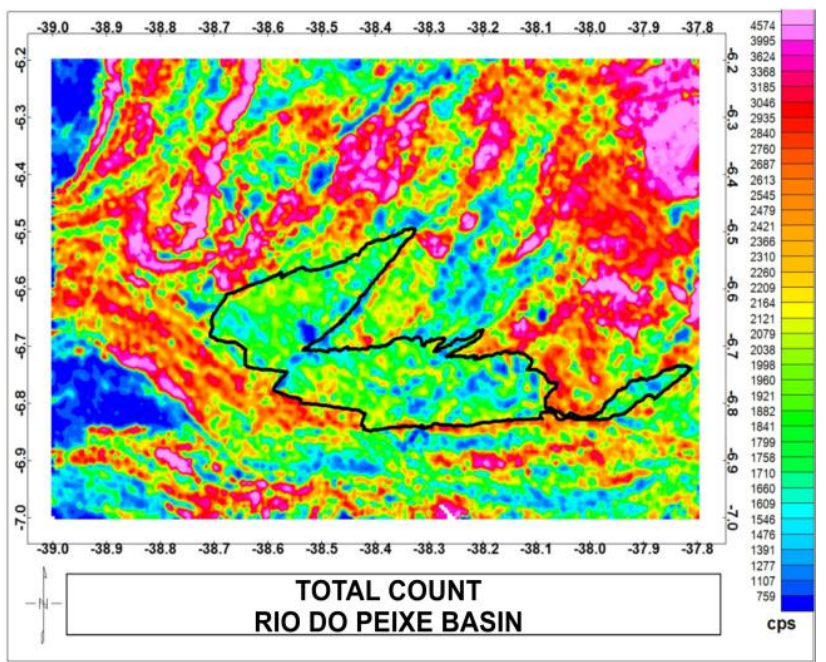

Figure 11: Two-dimensional image of the total count map.

The total count map reveals that the sediments in the basin (Sandstones, Argilites and Shales) had a low natural radioactivity count ranging from approximately 1200 to 2000 cps. The crystalline basement with the highest altitudes around the basin, formed by granitoids and gneisses, had the highest count.

The ternary map was constructed based on the normalization of the potassium, thorium and uranium counts (Figure 12).

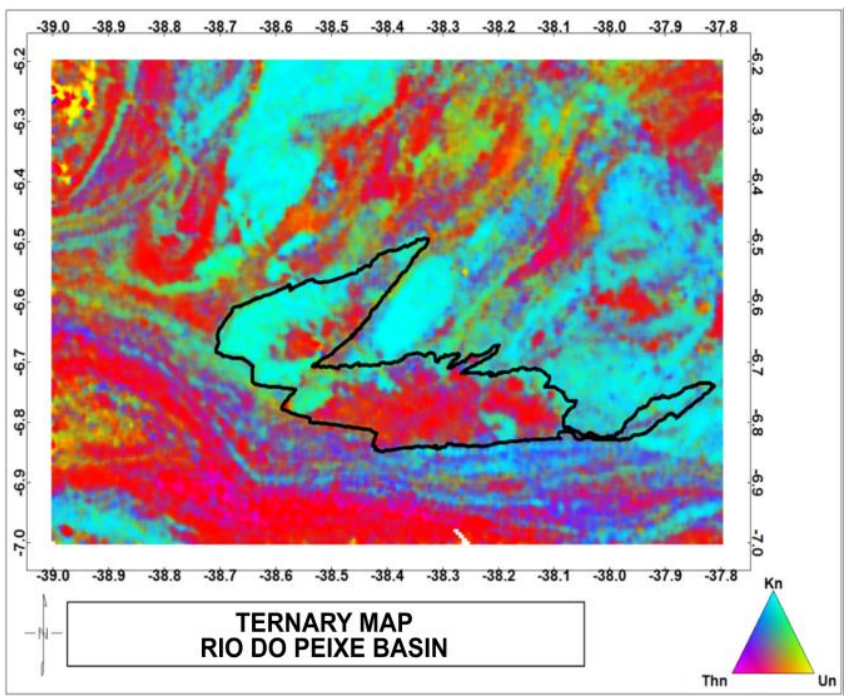

Figure 12: Ternary map of the Rio do Peixe basin. 
The ternary map indicates that the Souza formation is dominated by thorium count. The Antenor Navarro and Rio Piranhas formations are dominated by potassium, with no significant uranium dominance within the basin. The map also allows to view the geologic lineaments around the basin.

\section{CONCLUSIONS}

This paper presented the theoretical basis of the radiometric method and its applications. Furthermore, it was presented the main characteristics of the Rio do Peixe basin, which is an important land basin in the interior of Brazil with proven and already auctioned oil fields. The mapping of the uranium, potassium and thorium counts in the Rio do Peixe basin region was obtained. The obtained maps were correlated with the geological and topographic mapping of the region. In general, the basin sediment, formed mainly by sandstones, argilites and shales, presented low counts of natural radioactivity when compared to the basement around the basin formed mainly by granites and gneisses. The radiometric maps of total and ternary counting illuminated the geologic lineaments. The potassium, thorium and ternary maps, on the other hand, made it possible to identify and separate the Rio Piranhas, Souza and Antenor Navarro geological formations. Finally, the maps produced provide a radiometric basis that can be used in other studies such as geological, geochemical and environmental.

\section{REFERENCES}

[1] SILVA, J.R.S. Estudo do Levantamento Aerogeofísico do Estado do Rio de Janeiro na Região dos Lagos. Ph.D. Thesis, Observatório Nacional, Rio de Janeiro. 2007.

[2] KEAREY, P.; BROOKS, M.; HILL, I. An Introduction to Geophysical Exploration. $3^{\mathrm{a}}$ ed. Oxford: Blackwell Science, 262p. 2002.

[3] SILVA, A. N. Arquitetura, litofácies e evolução tectono Estratigráfica da bacia do Rio do Peixe, Nordeste do Brasil. Dissertação de Mestrado - Universidade Federal do Rio Grande do Norte - UFRN. 2009.

[4] FONTES, C. Q. Nona Rodada de Licitações - Bacia do Rio do Peixe. ANP Superintendência de definição de blocos. 2007.

[5] GAlvÃO, M. J.; ROCHA, D. E.; AMARAL, C. A; FILHO, W. D. Hidrogeologia Da Bacia Sedimentar Do Rio Do Peixe-Pb. Fundo Setorial de Recursos Hídricos Financiadora de Estudos e Projetos, Campina Grande, p. 56, 1 out. 2007.

[6] LIMA FILHO, M.F. 1991. Evolução tectono-sedimentar da Bacia do Rio do Peixe - PB. (Universidade Federal de Pernambuco). Dissertação de Mestrado, 99 p.

[7] ROCHA, D., AMARAL, C., Comportamento das Bacias Sedimentares da Região Semi-Árida do Nordeste Brasileiro. Fundo Setorial de Recursos Hídricos. 2006.

[8] FAURE, G. Principies of Isotope Geology. 2 ed. xv + 589 pp. Nova Iorque, Chichester, Brisbane, Toronto, Cingapura: John Wiley \&amp; Sons. 1986.

[9] ZIESSMAN, H. A.; THRALL, J. H. Medicina Nuclear. 4. Ed. RJ: Elsevier, 2014. 1496 p. 2014.

[10] TRIGUEIRO, E. História do universo. 1. Ed. SP: Novo Século. 125 p. 2016.

[11] VASCONCELLOS, R. M.; METELLO, M. J.; MOTTA A.C.; GOMES R. D. Geofísica em levantamentos geológicos. Rio de Janeiro: CPRM. p 165.

[12] TELFORD, W.M; GELDART, L.P; SHERIFF, R.E. Applied Geophysics. Cambridge: Cambridge University Press 770p. 1990.

[13]] COETZEE, H.; LARKIN, J. Application of the airborne radiometric method in radiation protection applications. 2009.

[14] AgUiAR, V. X. Sensores Aerotransportados Passado, Presente e Futuro. II Jornada de Sensoriamento Remoto de Defesa. 2003.

[15]SÁ C.B.; RIBEIRO, A.S. SANTOS, H.S.; FREITAS F.B.V. Processamento de Dados Aerogamaespectrométricos e sua Contribuição para o Conhecimento da Geologia da Região de Casimiro de Abreu. Revista de Engenharias da Faculdade Salesiana n. 5 pp. 27-36. 2017.

[16] BRITO, S, P., PORSANI, J.L., FIGUTI, L., DeBLASIS, P. Aplicação de métodos geofísicos em Arqueologia: primeiros resultados obtidos no sambaqui fluvial Capelinha, Cajati-SP, Brasil. Rev. do Museu de Arqueologia e Etnologia, São Paulo, 72: 43-54, 2002.

[17] PITKIN, J.A., DUVAL J.S. Design Parameters for Aerial Gamma-Ray Survays. Geophysics. 46(10):1474. 1980. 